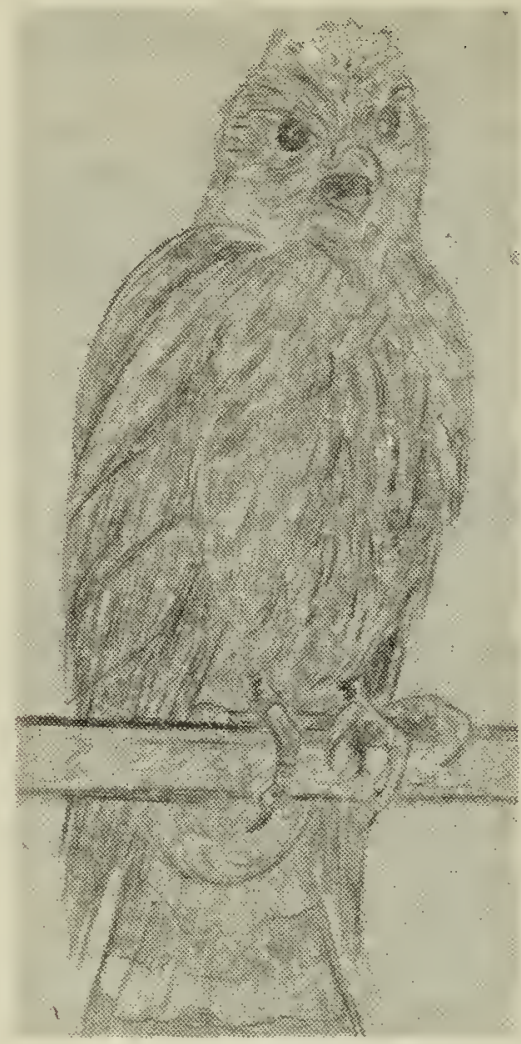

Pigeon Hawk

(Sketch done from a captive bird)

by Herbert Hlady, 15, Churchbridge, Sask.

\section{Saskatchewan Mice}

By Carol Van Dyck, age 11, 519-3rd Street E., Saskatoon

(The following was written by Carol for a public speaking contest after she became interested in mice through a visit to the Saskatchewan Museum of Natural History.)

I would like to tell you something about little animals in Saskatchewan that no one ever talks about very much, and that's Saskatchewan's mice. First, I should tell you the difference between a rat and a mouse is mainly in the name because some little animals that are called rats are really only the size of mice.

There are seventeen different kinds of mice found in Saskatchewan and these are divided into four different types. There are two that carry their food in the pockets in their cheeks - these are the pocket mice and kangaroo rats.

Then there are eleven kinds of ordinary mice and rats such as: grasshopper mouse, deer mice, whitefooted mouse, red-backed and ordinary meadow mouse, the lemming, the little upland, the pygmy and the one with the hardest name-the Phenacomys mouse. Then there are the muskrat and the woodrat. The two kinds of mice that jump are called the jumping mouse and the western jumping mouse. Saskatchewan also has two kinds of mice that really don't belong here but were brought in by settlers . . . they are the ordinary house mouse and the Norway rat.

One of the mice I think is the most interesting was found only two or three years ago in Saskatchewan and is called the kangaroo rat-and it really isn't either a kangaroo or a rat. This mouse is almost nine inches long, but most of that is tail. It has very long hind legs. It's easy to tell its footprints because the long tail leaves a trail between them as it hops along in the sand. The kangaroo rat has only been found in one place in Saskatchewan-in the sand hills south of Sceptre. It was first discovered by a man named Mr. Buscholl. who lives there. He wrote the Saskatchewan Museum about these strange little animals and the museum men went out and captured some of them. They had to do this at night because the kangaroo rat comes out only at night. It digs its little holes in the side of sand banks and covers its door when it goes into sleep and has to dig its way out again every night. The best time to see one is at four o'clock in the morning in the summer because it is one of the two Saskatchewan mice that hibernates in the winter. The other is the jumping mouse.

The kangaroo rat lives on seeds and insects and it can go for weeks without any water. It carries its food in pockets in its cheeks, and is very shy.

There is one use for mice that mos: people don't think of, and that is 0 : house pets. When Grant MacEwan who lives in Calgary, was out in : field one day about three years ago he found an ordinary little fielc mouse and took it home to his dau. ghter, Heather. Heather called thi mouse, Hillary, and he still live with the MacEwans and is a ver: spoiled fat little mouse. His milk ha to be sweetened with corn syrup an he especially likes fresh nuts an chocolate pudding, but will not ea cheese. When Mrs. MacEwan vacu ums she has to be careful not $t$ vacuum up Hillary. The only tim the MacEwans have trouble with hin is when they go on holidays becaus no one wants to look after their pe mouse. So the next time you see on of our little Saskatchewan mice, eve a Phenacomys, don't scream make him a dish of chocolate pud ding instead and you might have new little friend. 